\title{
PRAIRIE ANT COLONY LONGEVITY AND MOUND GROWTH
}

\author{
By Gregg Henderson ${ }^{1}$, Russel O. Wagner ${ }^{2}$, \\ AND ROBERT L. JEANNE ${ }^{1}$
}

\section{INTRODUCTION}

Of the social Hymenoptera (ants, some bees, and some wasps), colonies of ants appear to live longest. However, little information bearing on ant colony longevity exists (Wilson, 1971; Tschinkel, 1988), and much of it is anecdotal. Darwin (1859), for example, commented that some ant colonies must live as long as a human generation, and Forel (1928), fascinated by a colony of Formica pratensis in his childhood, found the nest still active 56 years later. Donisthorpe (1915) knew of a rufa nest in Weybridge, England, that was active for at least 20 years.

More recently, long-term monitoring of mound growth has been conducted in an attempt to understand colony population dynamics (Andrews, 1925; Dreyer and Park, 1932; Dreyer, 1942; Scherba, 1958; Talbot, 1961). Dreyer (1942) projected a 25- to 30-year maximum colony lifetime for Formica ulkei Emery, based on average changes in mound size for a population of colonies. Andrews (1925) took mound measurements for 19 years on a single nest of Formica exsectoides Forel, showing a clear exponential growth in mound size in the first half of the colony's life. Recently Tschinkel (1988) found that colony growth in Solenopsis invicta Buren fits a logistic curve, supporting the hypothesis that the growth of social insect colonies is regulated by density-dependent negative feedback mechanisms (Wilson, 1971; Oster and Wilson, 1978; Levings and Traniello, 1981; Hölldobler, 1986; Rissing, 1987; Tschinkel, 1988).

Individual ant-mounds of the prairie ant, Formica montana Emery, discovered in a prairie remnant in southwestern Wisconsin, were mapped in 1956. Here we report on the survivorship of 69 nests during the next 33 years. We also present 31 years (1957-1987) of data on growth patterns of eight of the original mounds that were

1) Department of Entomology, University of Wisconsin-Madison, Madison, Wisconsin 53706.

2) N6706 Shorewood Hills Road, Lake Mills, Wisconsin 53551

Manuscript received by the editor August 6, 1989. 
still active in 1988. This represents the most extensive longitudinal study on a population of social insect colonies to date.

\section{FORMICA MONTANA}

$F$. montana is a mound-building member of the fusca group that prefers sunny places and damp soil (Francoeur, 1973). Insolation of the relatively bare mound helps to regulate temperatures inside to levels that are optimal for brood development (Andrews, 1927; Scherba, 1958, 1961; Wilson, 1971; Bruskewitz, 1981). Gregg (1948) regarded the prairie ant, $F$. montana, a subdominant species, if not a true ecological dominant. F. montana builds mounds of excavated soil that may occupy up to $1.7 \%$ of the surface area of a prairie, and are considered to be one of the most important biotic forces in the prairie environment (Baxter and Hole, 1967; Fig. 1). Homopteran honeydew, a major dietary constituent for $F$. montana, is supplied by a complex of prairie plants on which the homopterans reside throughout the foraging season (Henderson, in preparation).

\section{STUdy Site}

Ipswich Prairie is a $1500 \mathrm{~m}$ by $10 \mathrm{~m}$ prairie remnant located along a railroad right-of-way on the Grant-LaFayette County line in southwestern Wisconsin. Over 120 native prairie plant species are located at Ipswich Prairie, and of Curtis' (1955) 50 prairie plant indicator species, 31 are present (Wagner, 1960). The Wisconsin Scientific Areas Preservation Council (Natural Areas now) initiated acquisition of Ipswich Prairie about 1979 and now has it listed as one of over 200 such areas.

\section{Methods}

In 1956 , four $150 \mathrm{~m} \times 1 \mathrm{~m}$ transects along the $1500 \mathrm{~m}$ length of Ipswich Prairie were established by one of us (ROW) and all nests of $F$. montana located within their boundaries were mapped. The presence of ants entering or exiting nest holes and/or the condition of the nest (e.g., whether the nest showed signs of recent excavation) were used as indicators of nest activity. Abandoned nests lacked recently excavated entrances and other signs of ant activity. 


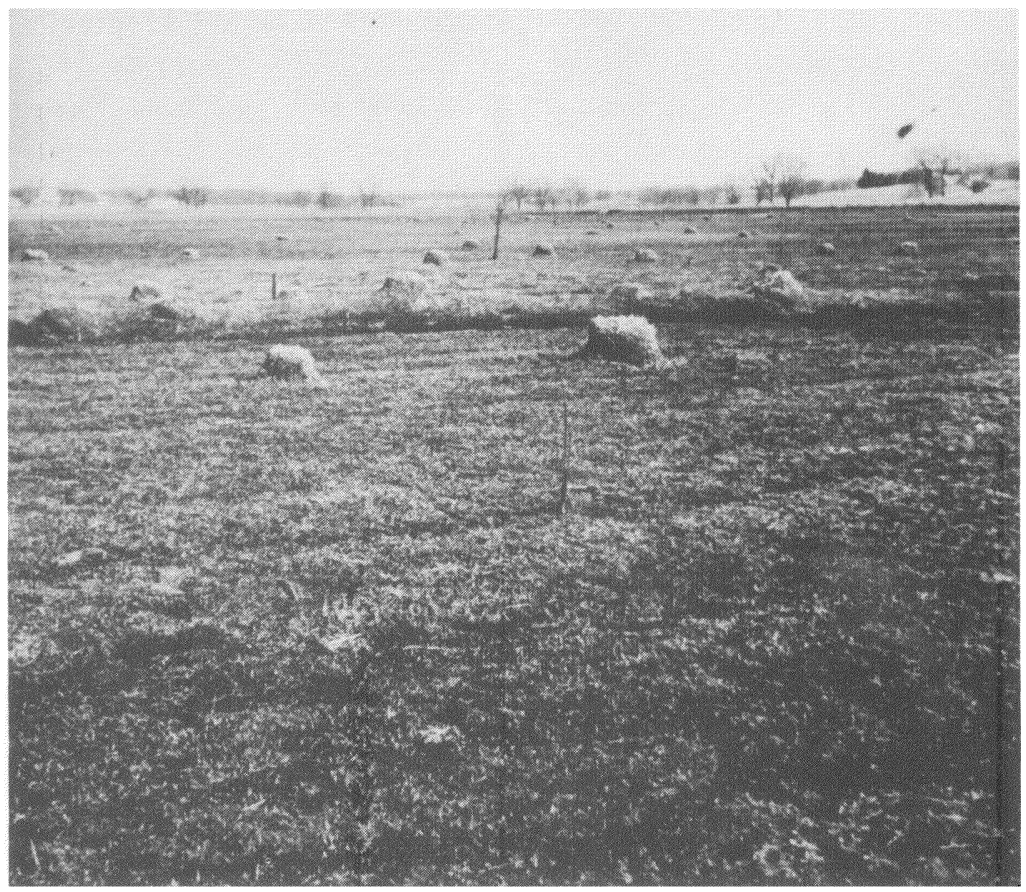

Fig. 1. Formica montana mounds in Green Prairie (University of Wisconsin Arboretum, Madison, WI), after a prairie fire. Photograph taken in 1940s.

As a non-destructive estimator of colony size, mound measurements were taken in mid-summer or early fall every year between 1957 and 1962, and intermittently thereafter through 1987. The volume of each mound was estimated by using its length, width and heighi to compute the volume of a cylinder.

To establish the correlation between mound volume and colony size in F. montana, forty ant colonies were dug in 1957 and 1958 (outside of the four transects) and the ants counted. Colonies having mounds of rather uniform size $(15 \mathrm{~cm} \times 15 \mathrm{~cm} \times 13 \mathrm{~cm}$, length, width and height) were selected, and the dry weight and volume of soil in each mound was determined. The number of workers inhabiting a colony positively correlated with mound volume at the $1 \%$ level (J. T. Medler, unpublished data). Mound size for other ant 
species is also considered a good approximation of colony population size (Andrews, 1925; Weber, 1935; Scherba, 1958; Talbot, 1961; Wilson, 1971; Tschinkel, 1988; but see Porter and Jorgensen, 1988).

Multiple regression analyses (via Minitab) were used to evaluate the pattern of mound volume changes for the eight longest-lived nests. We used indicator variables $\left(\mathrm{X}_{2}=1\right.$ if a mound had not yet reached maximum volume, $X_{2}=0$ for each subsequent year after reaching maximum volume) to determine if the data points for each nest best fit a line that showed 1) a significant growth phase and decline phase, 2) a growth phase with no subsequent decline, or 3) no significant change in volume throughout the 31-year period.

Regression equation: $y=B_{0}+B_{1} X_{1}+B_{2} X_{2}+B_{3}\left(X_{1} X_{1}\right)$, where $\mathbf{Y}=$ mound volume, $\mathbf{B}_{0}, \mathbf{B}_{1}, \mathbf{B}_{2}, \mathbf{B}_{3}$, = constants, $\mathbf{X}_{1}=$ year, $\mathbf{X}_{2}=$ indicator variable; Minitab automatically eliminated the $\left(X_{1} X_{2}\right)$ combination if it was highly correlated with the other $\mathrm{X}$ variables.

\section{RESULTS}

From observations of nests outside of the transects it was apparent that prairie ants initiate two kinds of new colonies, permanent and temporary, or food-source mounds. Food-source mounds were often located about the stems of prairie plants, found most commonly associated with the prairie rose, Rosa arkansana and the cone flower, Ratibida pinnata. Excavations of these nests showed that about two dozen workers and a species of aphid they were tending were in residence. Food-source mounds were most often initiated in June, but did not grow in size and often disappeared by late season.

Of $58 \mathrm{~F}$. montana colonies in the four $150 \mathrm{~m} \times 1 \mathrm{~m}$ transects in 1956, survivorship was $40(69 \%)$ after 10 years, $28(48 \%)$ after 23 years, and 8 (14\%) after 33 years (Fig. 2). Three of the 18 nests that disappeared between 1956 and 1966 lost their identities through merging with closely adjacent colonies, indicating that polydomy occurs in this species. Most of the 58 mounds were already of moderate size $($ mean $=38 \mathrm{~cm} \times 39 \mathrm{~cm} \times 25 \mathrm{~cm})$ in 1957 and had probably been founded several years before 1956. Between 1956 and 1959 mounds ranged in size from the newly initiated (measuring less than $5 \mathrm{~cm} \times 5 \mathrm{~cm} \times 5 \mathrm{~cm})$ to some of the largest $(1 \mathrm{~m} \times 1 \mathrm{~m} \times 23$ $\mathrm{cm})$. 


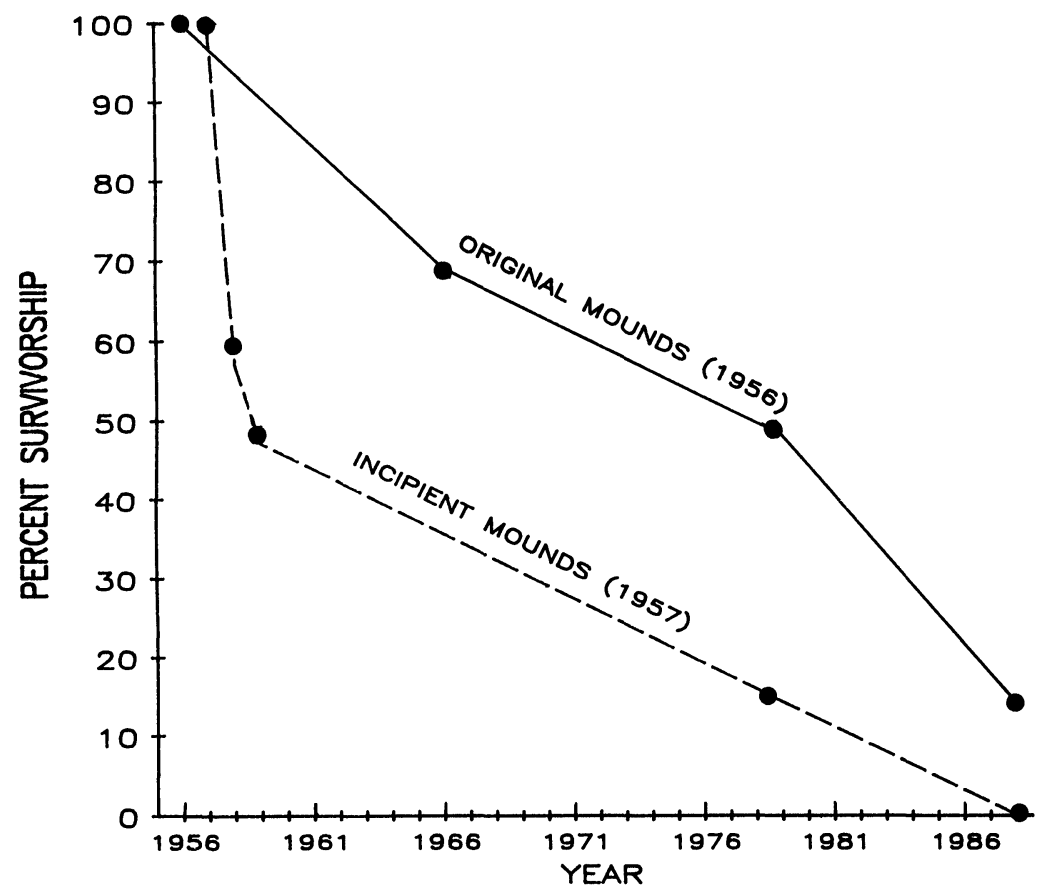

Fig. 2. Comparison of survivorship curves of established $F$. montana mounds with incipient mounds. Lines are interpolated from data points. See text for details.

In 1957, 21 new mounds were recorded. Of these, $12(57 \%)$ were active in 1958, $10(47 \%)$ in 1959 , three (14\%) in 1979, and none were active in 1988 (Fig. 2). In contrast, of 40 food-source mounds recorded in June 1959, 38 (95\%) disappeared by the end of August 1959.

The relatively large volumes of six of the eight mounds in 1957 (all except nests $c$ and $g$ ) indicated that they were initiated some years before recordings started (Fig. 3; Appendix I). Nest mound $h$ grew very little over the 31-year census (Fig. 3h; Table I). Volumes of nest mounds $a, b, c$, and $f$ increased rapidly and then declined, the decline starting between 1973 and 1979. Part of colony decline was coincident with the beginning of a reduced burning schedule for the prairie. Following the last regular burning of Ipswich Prairie in 1964 woody species (especially sumac and black cherry) began to invade 
the prairie, and by 1979 these had completely displaced native prairie plants in some locations. In 1979, ROW noted that in one invaded area $76 \%$ of the colonies died out, whereas $39 \%$ die-out was recorded in a relatively little-affected portion.

The dramatic mound volume increase by nest $a$ in 1973 was due to its merger with a nearby mound. The next measurement year however, mound volume dropped just as dramatically. Nest mounds $d$ and $e$ showed a positive growth at first, then leveled off. Nest $g$ grew in mound volume throughout the observation period. $92 \%$ of the variance in nest $g$ 's volume can be explained by the year.

Nest mounds showing a significant change in volume were collectively analyzed in two groups according to year of colony founding. Since nest mounds $a$ and $h$ had essentially no sustained growth phase (Table I; Fig. 3) they were omitted from the analysis. Nest mounds $c$ and $g$, whose small initial mound volumes in 1957 indicated they were probably incipient colonies in 1956, were analyzed together (group I). Nest mounds $b, d, e$ and $f$ had larger mound volumes in 1957, suggesting they were all initiated at some earlier date than nests $c$ and $g$. We analyzed these nest mounds as group II.

For each group, mound volume was regressed on year to determine if the pattern growth was logistic (an S-shaped curve), or more like a truncated $S$ curve (such that the bottom of the $S$ was cut off). Data were transformed using the guidelines given by Chatterjee and Price (1977: 29):

Logistic Equation Transformation: $\mathrm{Y}=\ln (\mathrm{Y} / 1-\mathrm{Y})$;

Truncated $S$ Transformation: $X=\ln (X)$;

where $\ln =$ natural logs, $Y=$ volume, $X=$ year.

The truncated $S$ transformation gave the better fit for both groups (Table I). However, only data for group I are valid for evaluating mound growth for newly initiated colonies, since start-up year for colonies of group II was not known. Nests of group II may have had a phase of exponential growth prior to 1956.

\section{Discussion}

Interpreting the growth pattern of $F$. montana colonies requires that we consider the constraints that help shape it. To do this we must know some of the biology of $F$. montana. $F$. montana is multicolonial: workers distinguish nestmates from alien conspecifics and they aggressively defend food-territories from nearby colonies 
Table 1. Best fit regression line for mound a-h growth patterns. Nest groups I and II show fit of data to a logistic growth model and a truncated $\mathrm{S}$ growth model. $\mathrm{Y}=$ mound volume, $\mathrm{X}=$ year, $\mathrm{I}=$ indicator variable, $\mathrm{ln}=$ natural $\operatorname{logs}, \mathrm{P}=$ significance level, $\mathrm{R}^{2}(\%)=$ Percent of variance in mound volume explained by the $\mathrm{X}$ azis variables.

\begin{tabular}{|c|c|c|c|c|}
\hline Nest & \multicolumn{2}{|c|}{ Regression equation } & $\mathbf{R}^{2}(\%)$ & $\mathbf{P}$ \\
\hline a & \multicolumn{2}{|c|}{$y=0.103-0.0001 X-0.06 \mathrm{I}+0.005(X \mathrm{I})$} & 45 & $>.10$ \\
\hline b & \multicolumn{2}{|c|}{$\mathrm{y}=0.27-0.005 X-0.24 \mathrm{I}+0.01(X \mathrm{I})$} & 86 & $<.001$ \\
\hline c & \multicolumn{2}{|c|}{$y=0.09-0.0001 X-0.105 I+0.006(X I)$} & 96 & $<.001$ \\
\hline d & \multicolumn{2}{|c|}{$y=0.02+0.003 X+0.013 I$} & 80 & $<.001$ \\
\hline e & \multicolumn{2}{|c|}{$y=-0.007+0.003 X+0.038 I$} & 84 & $>.05<.10$ \\
\hline f & \multicolumn{2}{|c|}{$y=0.08+0.00002 X-0.046 I+0.005(X I)$} & 68 & $<.05$ \\
\hline g & \multicolumn{2}{|c|}{$y=0.00065+0.0036 X$} & 92 & $<.001$ \\
\hline $\mathrm{h}$ & \multicolumn{2}{|c|}{$y=0.06+0.0003 X-0.01 I+0.002(X I)$} & 51 & $>.10$ \\
\hline \multirow[t]{2}{*}{ Group I } & $\{\ln (X)\}$ & $y=-0.045+0.039 x$ & 85 & $>.05<.10$ \\
\hline & $\{\ln (y / 1-y)\}$ & $y=-5.88+0.15 X$ & 52 & $>.10$ \\
\hline \multirow[t]{2}{*}{ Group II } & $\{\ln (X)\}$ & $y=0.012+0.029 x$ & 64 & $>.05<.10$ \\
\hline & $\{\ln (y / 1-y)\}$ & $y-3.09+0.036 x$ & 54 & $>.10$ \\
\hline
\end{tabular}

of conspecifics (Henderson, in preparation). Nevertheless, several other attributes of $F$. montana are normally associated with a unicolonial species (sensu Wilson, 1971; Hölldobler and Wilson, 1977; but see Rissing and Pollock, 1988): they occur in patchily distributed habitats, monopolize the habitat by excluding other ant species, build large, aggregated populations of colonies through budding, and are polygynous (Henderson, in preparation).

Ant colony growth most often appears governed by the food limitations of the habitat, a density-dependent controlling mechanism (Brian, 1953, 1957; Wilson, 1971; Rissing, 1978; Tschinkel, 1988). This may be going on in F. montana as well. That is, the behavior of territoriality between $F$. montana colonies limits a colony's access to food and thus governs the density-dependent negative feedback that regulates colony growth. This provides a means by which a single species may populate a habitat and not overexploit its food supply.

While the carrying capacity of the prairie habitat for $F$. montana may be set by food resources accessible to the territorial colonies, density-independent factors affecting habitat quality also appear to influence colony size and density in this population. The correlation of the decline of $F$. montana colonies with the cessation of annual 


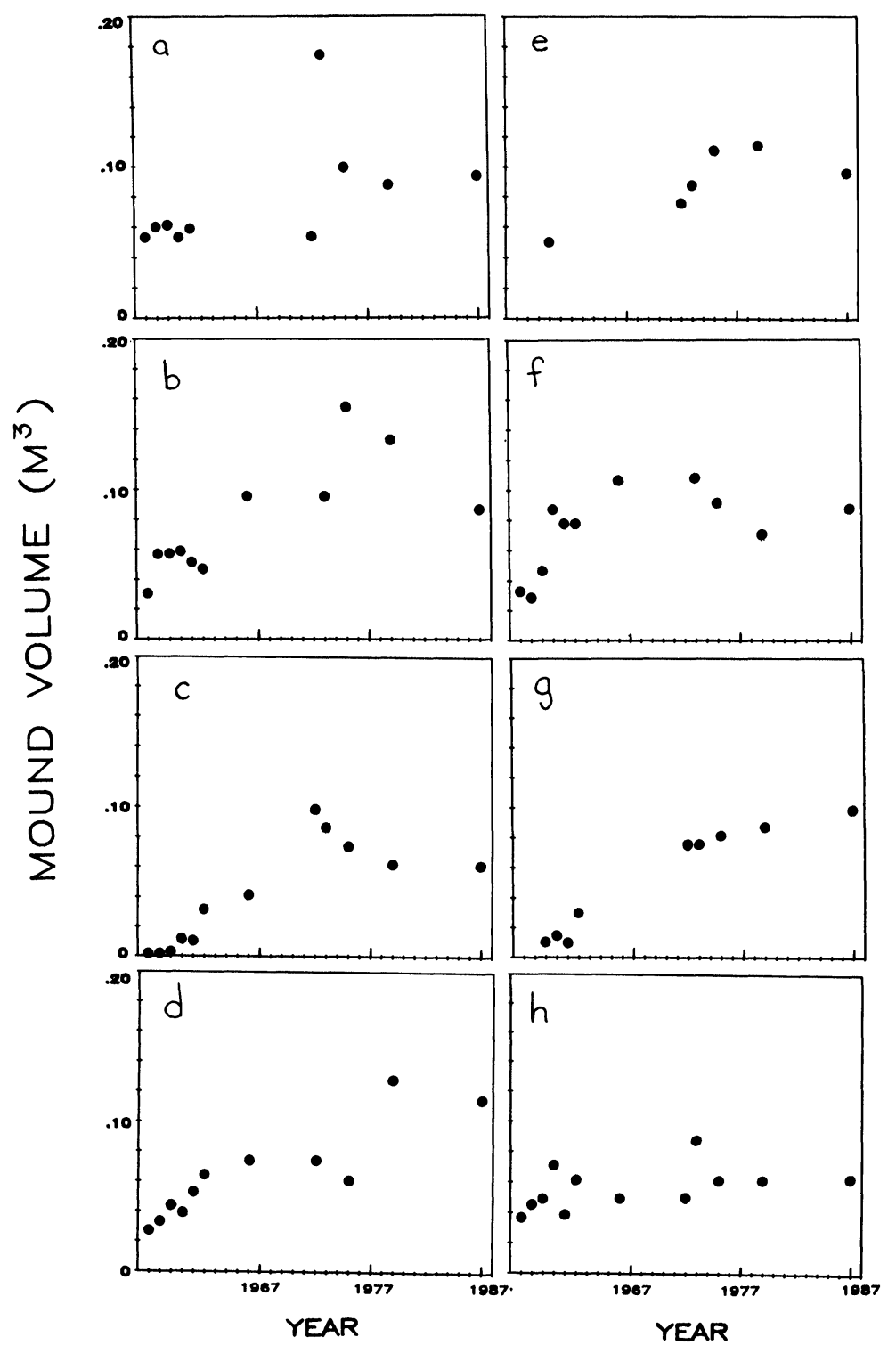

Fig. 3. Mound volume $\left(\mathrm{m}^{3}\right)$ as a function of year for eight Formica montana colonies censused over a 31-year period. 
burning and the subsequent invasion of woody plant species at Ipswich Prairie suggests that the one was the effect of the other. The increasing shade imposed by the invading species could well have reduced the quality of the habitat, either directly by its negative effects on nest mound temperature, or indirectly via its influence on the growth of the prairie plant species harboring the homopterans whose honeydew is an important food source for this ant.

\section{SUMMARY}

Nest mound growth of a population of $F$. montana colonies was systematically measured over a 31-year period. Some nests were still active 33 years later and one nest was still in the growth phase in 1987. Regression analysis revealed that mounds grew quickly in the first years of life, suggesting that colony initiation through budding provides an efficient means of rapid growth at the point when colony survival is most in jeopardy. It is hypothesized that colony growth is mediated by intraspecific territoriality which limits a colony's access to food. Decline of the colony is correlated with density-independent factors.

\section{ACKNOWLEDGMENTS}

We are especially grateful to J. T. Medler for his expert contribution and interest in the earlier phases of this study. Joan M. Herbers, Sean O'Donnell, Edward O. Wilson and two anonymous reviewers are thanked for critically reading earlier drafts of this paper. The College of Agriculture and Life Sciences (CALS) Statistical Consulting Service provided us with advice on statistical procedures. This work was supported by: the Research Committee of the Graduate School of the University of Wisconsin and funds from the National Science Foundation (G-13320) to ROW and J. T. Medler (principal investigator), Federal Hatch Support Project No. 2588 to RLJ, grants from the Friends of the Arboretum, University of Wisconsin, to GH, and a grant from the Roger Tory Peterson Institute of Natural History to GH. The writers express their appreciation to W. L. Brown Jr. and A. Francouer for helpful determination of the ant species. 


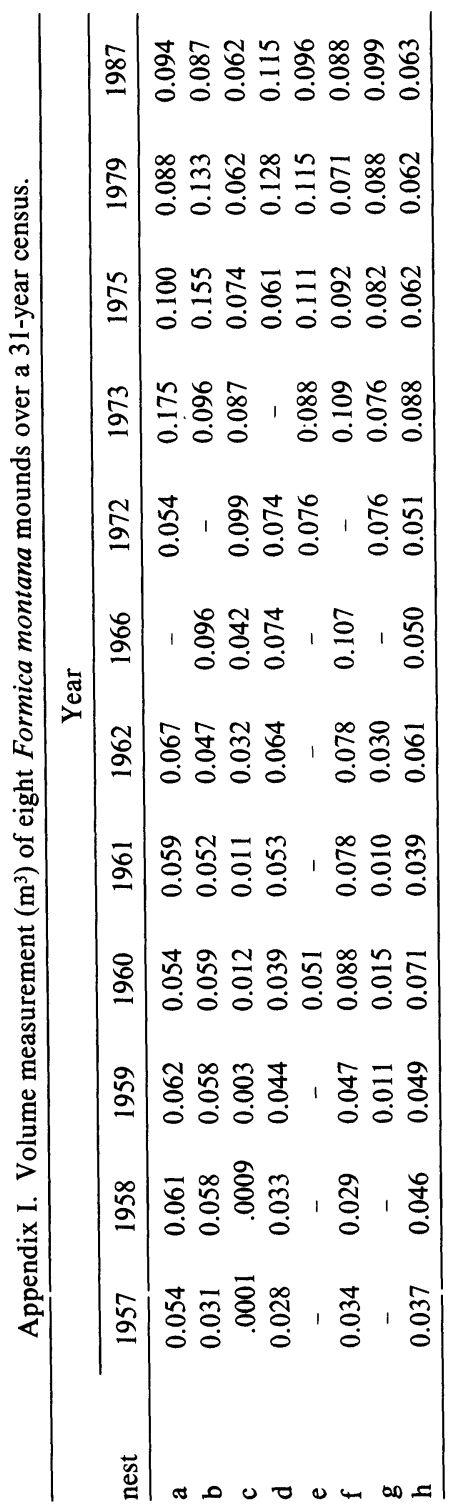




\section{Literature Cited}

Andrews, E. A. 1925. Growth of ant mounds, Psyche 32: 75-87.

ANDrews, E. A. 1927. Ant-mounds as to temperature and sunshine. J. Morphol. and Physiol. 44: 1-20.

Baxter, F. P., AND F. D. Hole. 1967. Ant (Formica cinerea) pedoturbation in a prairie soil. Proc. Soil Science Soc. Am. 31: 425-428.

BriAN, M. V. 1953. Brood-rearing in relation to worker number in the ant $M y r$ mica. Physiol. Zool. 26: 355-366.

Brian, M. V. 1957. The growth and development of colonies of the ant Myrmica. Insectes Sociaux 2: 1-34.

BRUSKEWITZ, J. W. 1981. Wetland ants: Internal mound temperature and humidity preferences; location and shape of mounds as adaptations to a wetland environment. Wisconsin Academy of Sciences, Arts and Letters 69: 21-25.

Chatterjee, S., and B. Price. 1977. Regression by example. John Wiley and Sons, New York.

CURTis, J. T. 1955. A prairie continuum in Wisconsin. Ecology 36: 558-566.

DARWIN, C. R. 1859. On the origin of species by means of natural selection, or the preservation of favoured races in the struggle for life. John Murray, London, England.

DonistoRPe, H. ST. J. K. 1915. British ants, their life-history and classification. William Brendon and Son, Ltd., Plymouth, England.

DreYer, W. A. 1942. Further observations on the occurrence and size of ant mounds with reference to their age. Ecology 23: 486-490.

Dreyer, W. A., AND T. PARK. 1932. Local distribution of Formica ulkei moundnests with reference to certain ecological factors. Psyche 39: 127-133.

Francoeur, A. 1973. Révision taxonomique des espéces néarctiques du groupe fusca genre Formica (Formicidae, Hymenoptera). Mémoirs of the Entomol. Soc. Québec, $316 \mathrm{pp}$.

Forel, A. 1928. The social world of the ants compared with that of man. G. P. Putnam's Sons Ltd., London, England.

GreGG, R. E. 1948. An unusual nest of the prairie mound building ant. Proc. Entomol. Soc. Wash. 50: 183-186.

Hölldobler, B. 1986. Konkurrenzverhalten und Territorialität in Ameisenpopulationen. pp. 25-70. In: Chemische Okologie Territorialität Gegenseitige Verständigung (Information Processing in Animals). T. Eisner, B. Hölldobler and M. Lindauer, eds. Gustav Fischer Verlag, New York.

Levings, S. C. AND J. F. A. Traniello. 1981. Territoriality, nest dispersion, and community structure in ants. Psyche 88: 265-319.

Oster, G. F. AND E. O. Wilson. 1978. Caste and ecology in the social insects. Princeton University Press. Princeton, NJ, USA.

Porter, S. D., AND C. D. Jorgensen. 1988. Longevity of harvester ant colonies in southern Idaho. J. Range Management 41: 104-107.

Rissing, S. W. 1987. Annual cycles in worker size of the seed-harvester ant Veromessor pergandei (Hymenoptera: Formicidae). Behav. Ecol. and Sociobiol. 20: 117-124. 
Rissing, S. W. And G. B. Pollock. 1988. Pleometrosis and polygyny in ants. In: Interindividual behavioral variability in social insects (ed. R. L. Jeanne). Westview Press, Boulder, CO.

SCHERBA, G. 1958. Reproduction, nest orientation and population structure of an aggregation of mound nests of Formica ulkei Emery (Formicidae). Insectes Sociaux 5: 201-213.

SCherba, G. 1961. Nest structure and reproduction in the mound building ant Formica opaciventris Emery in Wyoming. J. New York Entomol. Soc. 69: 71-87.

Talbot, M. 1961. Mounds of the ant Formica ulkei at the Edwin George Reserve, Livington County, Michigan. Ecology 42: 202-205.

TsCHINKEL, W. R. 1988. Colony growth and the ontogeny of worker polymorphism in the fire ant, Solenopsis invicta. Behav. Ecol. and Sociobiol. 22: 103-115.

WAGNER, R. O. 1960. Distribution patterns of some prairie plants and their relationships to methods of reproduction. Ph.D. Thesis, Dept. Botany, University of Wisconsin, Madison, WI.

Weber, N. A. 1935. The biology of the thatching ant, Formica rufa obscruipes Forel, in North Dakota. Ecol. Monogr. 5: 166-206.

Wilson, E. O. 1971. The insect societies. Belknap/Harvard Press. Cambridge, MA, USA. 

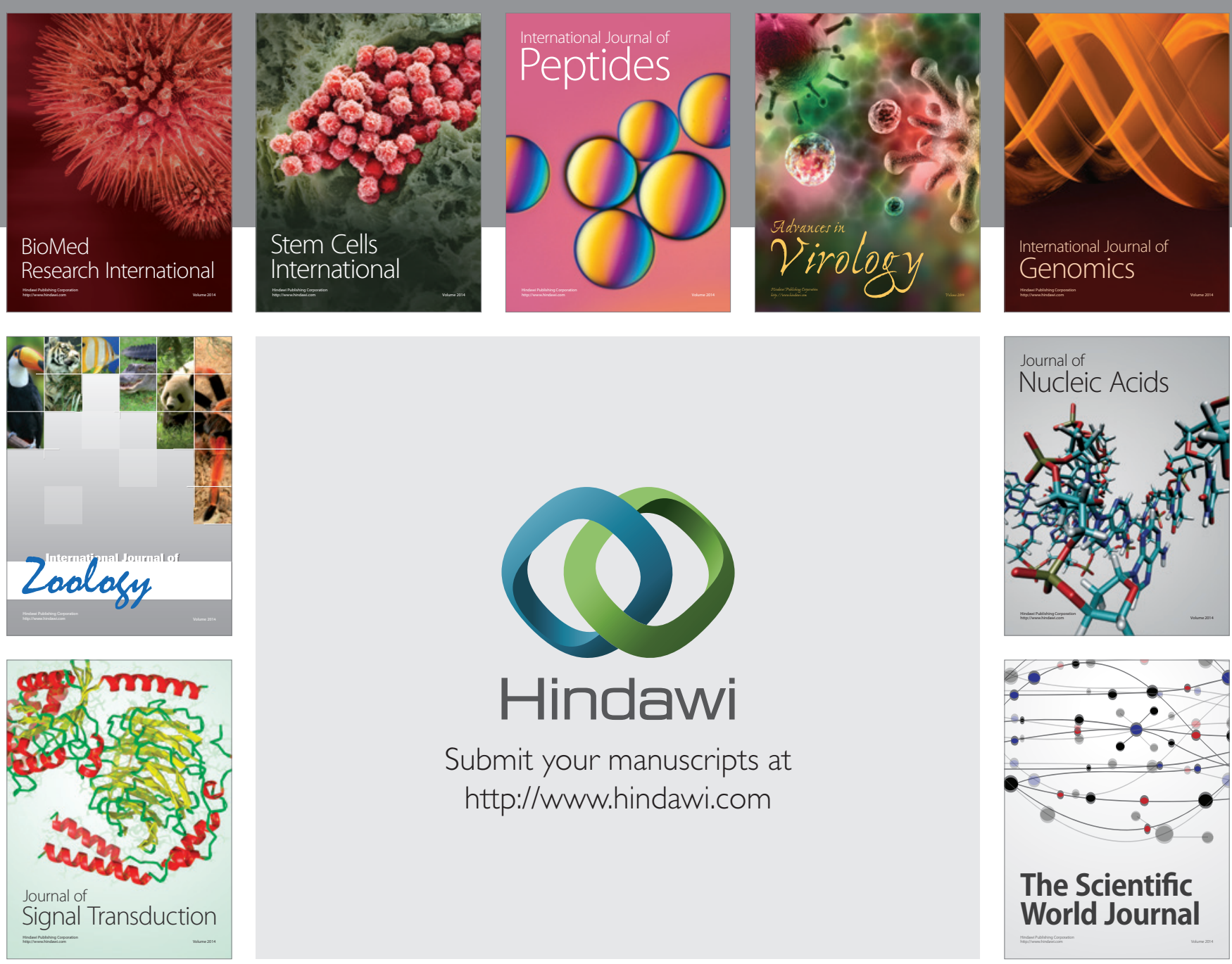

Submit your manuscripts at

http://www.hindawi.com
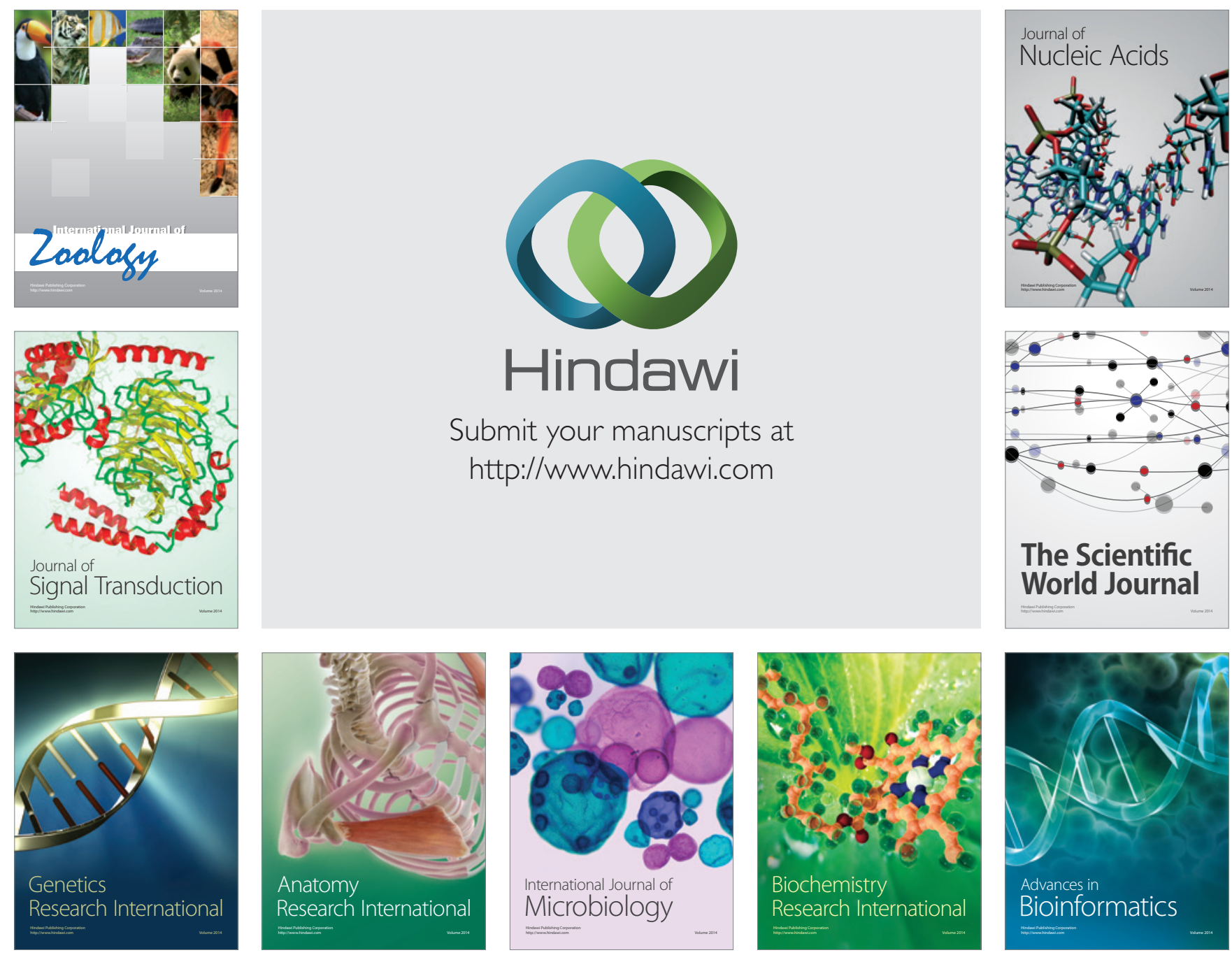

The Scientific World Journal
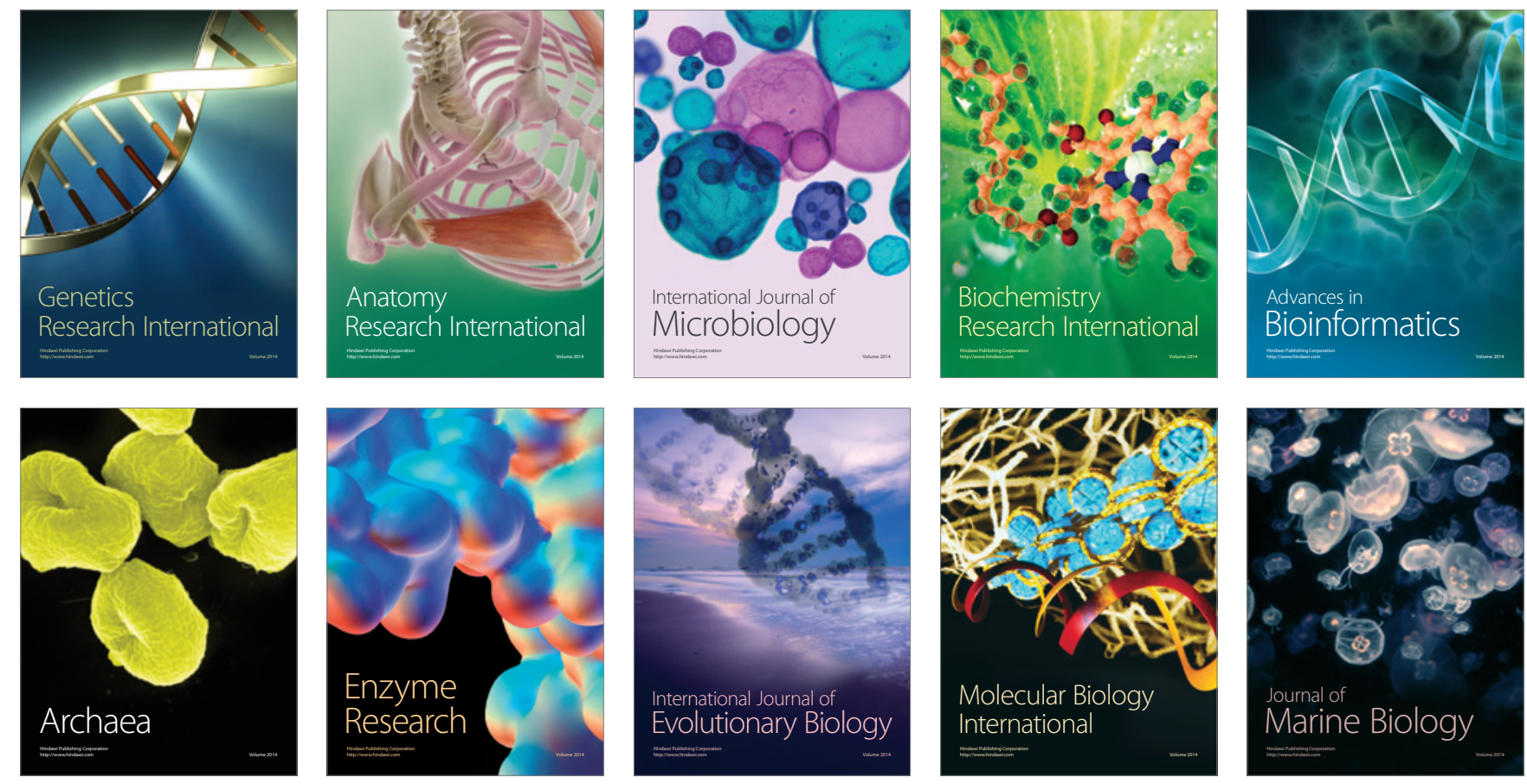